\title{
Komparasi Fuzzy AHP, TOPSIS dan SMART untuk pemilihan supplier
}

\author{
Comparison Fuzzy AHP, TOPSIS and SMART methods for suppliers selection
}

\author{
Samdan Wibawa ${ }^{\left.1^{*}\right)}$, AD Ekawati ${ }^{2}$, Budian Maryadi ${ }^{3)}$, Nurafni Fitriyani ${ }^{4)}$, AANP \\ Redi5) \\ 1,2,3,4,5) Industrial Engineering Department, BINUS Graduate Program - Master of Industrial Engineering, Bina Nusantara University, \\ Jakarta, Indonesia
}

\begin{tabular}{l} 
ARTICLE INFORMATION \\
\hline Article history: \\
Received: Agustus, 02, 2021 \\
Revised: Agustus, 23, 2021 \\
Accepted: Agustus, 25, 2021 \\
\\
Keywords: \\
Supplier selection \\
FAHP \\
TOPSIS \\
SMART \\
*Corresponding Author \\
Samdan Wibawa \\
E-mail: samdan.wibawa@binus.ac.id
\end{tabular}

\section{A B S T R A C T}

PT.XYZ is a manufacturing drilling tools company where the assembly parts are supplied by the other companies. With $4 \%$ average percentage of not good (NG) from incoming assembly inspections in 2019 and the peak of $9,8 \%$ in April, the company needs to review its current suppliers. This research compares the result of the supplier selection using FAHP, TOPSIS and SMART methods to get the recommended suppliers. The three methods resulted the same suppliers with the highest value which is Supplier\#3 and the three lowest values which are Supplier\#4, Supplier\#7 and Supplier\#2. Result study used as recommendations for company decision. Three suppliers with the lowest score are recommended to be terminated or re-evaluated. Using FAHP, TOPSIS and SMART methods to get the recommended suppliers.

This is an open access article under the $\underline{\mathrm{CC}-\mathrm{BY}}$ license.

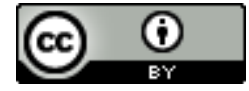

\section{INTRODUCTION}

As a drilling tools manufacturing company, PT. $\mathrm{XYZ}$ does not produce all assembly part themselves, but instead gets them from the supplies from other suppliers. PT XYZ has eight suppliers that supply assembly parts. The performance of PT. XYZ supplier that can be seen in Figure 1 shows the average percentage of Not Good (NG) incoming assembly part inspection in 2019 was 4\%, and the peak occurred in April with NG percentage of $9.8 \%$. The poor performance of the supplier will affect the company productivity. In this regard, it is necessary to evaluate the performance of the supplier. It is necessary to develop supplier assessment criteria and to use objective assessment methods, in the hope of getting the right supplier and can reduce the percentage of NG numbers.
Currently PT.XYZ does not yet have a supplier selection procedure and criteria in selecting suppliers. The selection of suppliers is carried out by conducting survey directly to the suppliers and then comparing the price among the suppliers. The current implementation of supplier selection is tend to be subjective without any fixed procedure and criteria. Supplier inconsistency in supplying parts is one of the company considerations. The company wants parts sent by suppliers to be good quality parts because there are often some parts that do not comply with company standards, causing delay in the arrival of parts to the warehouse which can cause further delay in the assembly process. Good service, ease of negotiation, payment system and competitive prices among suppliers are also other considerations to select suppliers. Some suppliers cannot meet the demand for raw materials at any time because the availability of raw materials in 
the supplier's warehouse is insufficient, so the company has to look for other alternatives. In addition, the distance between the supplier and the company has also an effect on shipping costs.

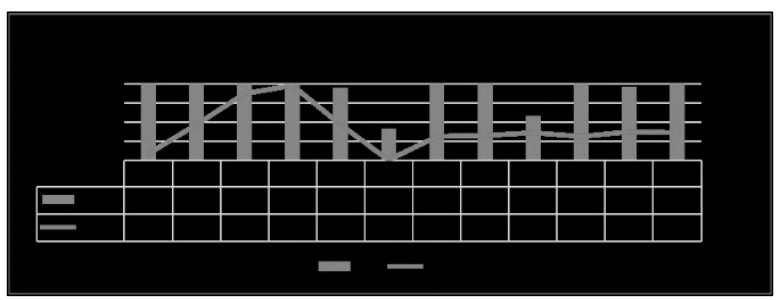

Figure 1. Percentage of incoming assembly parts inspection in 2019.

Supplier selection is part of supply chain management that must be well managed. Supplier selection affect the competitiveness of all supply chain activities [1]. Supplier selection is a long process, suppliers are evaluated in terms of several criteria such as price, delivery, quality, service and others. When evaluating several criteria, trade off often occur, such as there are suppliers who offer products with good quality but uncertain delivery. Supplier selection is a multicriteria decision, because each criterion used has different interests [2]. The main objective of the supplier selection process is to reduce risk and maximize buyer value [3].

Given this background, it is necessary to develop an assessment method for selecting and evaluating supplier performance, especially for incoming parts suppliers in this company, so that evaluation and selection can be carried out in a more structured, transparent and objective manner, thus the suppliers can understand the basis for the selection.

Given the conditions that occurred at PT. XYZ, it is necessary to apply a method of taking decisions that are able to accommodate differences in criteria and their interests in selection of incoming parts suppliers. Selection criteria is one of the important things in supplier selection [4] . Fuzzy AHP, TOPSIS and SMART methods are methods multi-criteria decision making that is able to accommodate the elements of subjectivity. Therefore, this research is expected to be a tool for companies in determining suitable suppliers as partners and suppliers who need to be replaced or re-evaluated.

In these types of problems, one of the major difficulties is handling the uncertainty. Decision making based on several criteria that have been set will be effective if using the right method, In this paper, we preferred using Fuzzy AHP, TOPSIS and SMART methods. These methods are compared because they have their respective advantages and disadvantages. The Fuzzy AHP method can eliminate subjectivity [5], because the assessment is converted into a triangular fuzzy number (TFN) [6]. The TOPSIS method emphasizes getting the optimal alternative with the stages. The TOPSIS method is based on the notion that the best decision should be the closest to the ideal solution and farthest from the non-ideal solution [7]. The SMART method is practical in its use, because the steps are simple, so this method is widely used [8]. The best analysis is transparent so this method provides a high understanding of the problem and is acceptable to decision makers.

\section{RESEARCH METHOD}

The application of multi criteria decision making (MCDM) in this study is a tool or method in making supplier selection decisions to determine the best alternative from a number of alternatives based on several criteria. The criteria price, quality, delivery and service are criteria that often appear in supplier selection [9]. The criteria, that will be used in this research are: price, quality, delivery and service. These criteria is obtained from the results of interviews with informants. The suppliers in this research are limited to only eight assembly parts suppliers.

This research was conducted in several stages consisting of systematic and directed steps for the implementation process. Literature studies are needed to support the author's understanding and knowledge of what materials, concepts, theories, and methods will be used in the study research process

Data collection is needed to obtain the data needed in building decision support for the selection of assembly parts suppliers. The technique used to collect data is by conducting interviews and questionnaires.

After getting the required data from the interviews and questionnairs, the next step is to process the data. Analysis of the selection of criteria is the process of determining the criteria that will be used as an element of decision making in a decision support system. In this study, the authors used the fuzzy AHP, TOPSIS and SMART methods. The following is the research methodology in figure 2 as follows: 


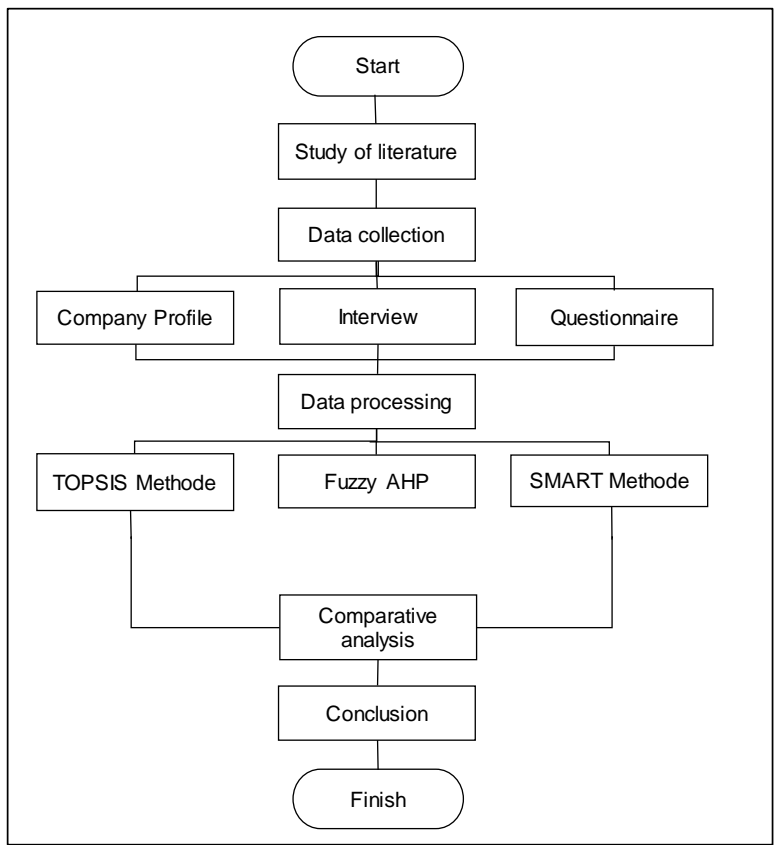

Figure 2. Research methodology.

Data were obtained through questionnaires and interviews with 12 respondents using in-depth interviews. The questionnaire consist of three types, questionnaire Fuzzy AHP, TOPSIS and SMART. Selected informants totaling 12, who could provide accurate information. The selected informants are informants who deal directly with suppliers in the company. Interviews and questionnaires were conducted to Subject Matter Experts (SME) in the procurement, assembly and QC incoming sections. This section is related to the performance of suppliers. The details of the subject matter experts (SME) are as follows table 1:

Table 1. Subject Matter Experts (SME)

\begin{tabular}{lc}
\hline \multicolumn{1}{c}{ Department } & Count \\
\hline Procurement Dept. & 4 \\
Assembly Dept. & 4 \\
QC Incoming Dept. & 4 \\
Total & $\mathbf{1 2}$ \\
\hline
\end{tabular}

2.1 Fuzzy Analytical Hierarchy Process (FAHP) FAHP is a multi-criteria decision making (MCDM) method and is a combination of the AHP method with a fuzzy concept approach. FAHP covers the weaknesses found in AHP, namely problems with criteria that have subjective characteristics. Fuzzy set theory helps in measurements related to the subjective judgment of humans using language or linguistics. Linguistic variables are definite and useful for processing information, within the fuzzy scope the triangular fuzzy number (TFN) is developed.
Fuzzy AHP is a hierarchical decision-making method. In constructing a hierarchy, first the problem is defined and decomposition, namely breaking the whole problem into its elements. In a complete hierarchical structure, the number of levels of factors depends on the selection of researchers. In general, the elements used in the hierarchy are factors, actors, goals, and alternatives [10].

The essence of the Fuzzy AHP method is the pairwise comparison with the ratio scale associated with the fuzzy scale value. Because a pairwise comparison matrix exists at each level, to get a global priority, a synthesis between the local priority must be done [11].

FAHP is a method that combines AHP with Fuzzy logic. In FAHP, the Fuzzy ratio scale is used to indicate the relative strength of the factors on the criteria concerned. The final score of the criteria is presented in Fuzzy numbers. The comparison matrix operation is performed using the Triangular Fuzzy Number (TFN), which is a Fuzzy number whose membership is defined by three real numbers as low, middle, upper [12], follows table 2:

Table 2. Triangular Fuzzy Number

\begin{tabular}{lc}
\hline \multicolumn{1}{c}{ Saaty Scale } & TFN \\
\hline 1 Equally important & $(1,1,1)$ \\
2 Weakly important & $(2,3,4)$ \\
5 Fairy important & $(4,5,6)$ \\
7 Strongly important & $(6,7,8)$ \\
9Absolutely important & $(9,9,9)$ \\
\hline
\end{tabular}

If the two triangular numbers are fuzzy $\mathrm{M} 1$ and $\mathrm{M} 2$ where $\mathrm{M} 1=(\mathrm{I1}, \mathrm{m} 1, \mathrm{u} 1)$ and $\mathrm{M} 2=(12, \mathrm{~m} 2, \mathrm{u} 2)$. Then the mathematical operation rules for triangular fuzzy numbers are [13]:

$$
\begin{aligned}
& \left(l_{1}, m_{1}, u_{1}\right)(x)\left(l_{2}, m_{2}, u_{2}\right)=\left(I_{1} I_{2}, m_{1} m_{2}, u_{1} u_{2}\right) \\
& (\lambda, \lambda, \lambda)(x)\left(I_{1}, m_{1}, u_{1}\right)=\left(\lambda I_{1}, \lambda m_{1}, \lambda u_{1}\right) \\
& >0, \lambda \in R \\
& \left(I_{1}, m_{1}, u_{1}\right)^{-1}=\left(\frac{1}{u 1}, \frac{1}{m 1}, \frac{1}{l 1}\right)
\end{aligned}
$$

In mathematics, the product of the cross Kronecker is denoted by is the operation of two vectors by multiplying according to their position, thus forming a vector of the same size. Logical consistency is an important characteristic of the FAHP. This is achieved by aggressing all eigenvectors obtained from various levels of the hierarchy and then obtaining a weighted vector 
composite that produces a sequence of decisions. Consistency testing is carried out to check whether the data obtained is valid or not. Valid data is reflected in data that has been consistent. The data considered to be consistent if the value of Consistency Ratio $(C R) \leq 0.10$. If the score is more than 0.10 , then the assessment of each expert should be reviewed and revised:

$$
\begin{gathered}
\mathrm{CR}=\mathrm{Cl} / \mathrm{RI} \\
\mathrm{Cl}=\left(\left(\lambda \_ \text {max }-\mathrm{n}\right)\right) /(\mathrm{n}-1)
\end{gathered}
$$

$\mathrm{Cl} \quad=$ Consistency Index

$\lambda \max =$ maximum eigenvalue of the pairwise comparison matrix

$$
\mathrm{n} \quad=\text { matrix order }
$$

The mean value of the Random Index (RI) according to Saaty can be seen in Table 3 [14]:

Table 3. Random Consistency Index $(R I)$

\begin{tabular}{lllllllllll}
\multicolumn{1}{l}{ Table } & 3. \\
\hline $\begin{array}{l}\text { Ordo } \\
\text { matriks }\end{array}$ & 1 & 2 & 3 & 4 & 5 & 6 & 7 & 8 & 9 & 10\{ \\
\hline $\mathrm{Rl}$ & 0 & 0 & 0,52 & 0,89 & 1,11 & 1,25 & 1,35 & 1,40 & 1,45 & 1,49
\end{tabular}

The steps of FAHP are weighting, TFN conversion, calculating geometric mean and fuzzy weight.

\subsection{Technique for Order Preference by Similarity to Ideal Solution (TOPSIS)}

The TOPSIS method was first introduced by Yoon and Hwang in 1981 as a multi-criteria decisionmaking method [15]. This method aims to determine the ideal positive solution and the negative ideal solution. The best alternative is chosen from the closest to the positive ideal solution and the one farthest from the negative ideal solution.

TOPSIS is based on the concept where the bestchosen alternative not only has the shortest distance from the positive ideal solution, but also has the longest distance from the negative ideal solution from a geometric point of view by using the Euclidean distance to determine the relative proximity of an alternative to the optimal solution. The positive ideal solution is defined as the sum of all the best achievable values for each attribute, while the ideal solution consists of all the worst achievable scores for each attribute. The positive solution maximizes the benefit criteria and minimizes the cost criterion, while the negative ideal solution maximizes the cost criterion and minimizes the benefit criterion [16].
The steps to solve problems using the TOPSIS method are as follows [17].

a. Build a normalized decision matrix. The elements resulting from normalization using the Euclidean length of a factor are:

$$
r_{i j}=\frac{X_{i j}}{\sqrt{\sum_{i=1}^{m} X_{i j}^{2}}}
$$

$x_{i j}=$ the original value of the decision matrix

$r_{i j}=$ normalized value of the decision matrix

b. Build a weighted normalized decision matrix with weights.

c. Determine the ideal positive solution and negative ideal solution, where $A+$ is a positive ideal solution while $A$ - is denoted as a negative ideal solution.
$\left.A^{+}=\left\{\left(\max v_{i j} / i \in j\right), \min v_{i j} \mid i \in j\right) \mid i=1,2, \ldots m\right\}=$ $\left\{v_{1}^{+}, v_{2}^{+}, \ldots v_{j}^{+}, \ldots v_{n}^{+}\right\}$

$\left.{ }^{4 A^{-}}=\left\{\left(\max v_{i j} / i \in j\right), \min v_{i j} \mid i \in j\right) \mid i=1,2, \ldots m\right\}=$ $\left\{v_{1}^{-}, v_{2}^{-}, \ldots v_{j}^{-}, \ldots v_{n}^{-}\right\}$

With,

$\mathrm{J}=\{\mathrm{j}=1,2, \ldots \mathrm{n}$ lj associated with benefit criteria $\}$ $\mathrm{J}=\{\mathrm{j}=1,2, \ldots \mathrm{n}$ lj associated with cost criteria $\}$

d. Measure the separation measure. Ideal separation and negative ideal separation

Ideal separation $\left.S_{i}^{+}=\sqrt{\sum_{j=1}^{n}\left(v_{i j}\right.}-v_{j}^{+}\right)^{2}$

Negatif separation $\left.S_{i}^{1}=\sqrt{\sum_{j=1}^{n}\left(v_{i j}\right.}-v_{j}^{-}\right)^{2}$

$\mathrm{i}=1,2,3, \mathrm{~m}$

e. Calculate the relative proximity to the ideal solution

$$
\begin{aligned}
& C_{i}^{*}=\frac{s_{i}^{+}}{S_{i}^{+}+S_{i}^{-}}, 0<C_{1}^{+}<1 i=1,2,3, \ldots m \\
& C_{i}^{*}=1 \text { jika } A_{1}=A^{+} \\
& C_{i}^{*}=0 \text { jika } A_{1}=A^{-}
\end{aligned}
$$

f. Ranking based on $\mathrm{C}_{\mathrm{i}}^{*}$ value

\subsection{Simple Multi Attribute Rating Technique (SMART)}

SMART uses a linear adaptive model to predict the value of each alternative. SMART is more widely used because of its simplicity in responding to the needs of decision makers and the way it 
analyzes responses. The analysis is best transparent so that this method provides a high level of understanding of the problem and is acceptable to the decision maker. The weighting on SMART uses a scale of 0 to 1 , making it easier to calculate and compare the values for each alternative. The stages in the SMART method are as follows [18] :

a. Calculating the normalized criteria weights by comparing the criteria weight values with the total criteria weights.

b. Determine the utility value by converting the criteria value for each criterion into the standard data criteria value. The utility value can be divided into 2, namely the cost criteria and the benefit criteria. The utility equation for the cost criteria can be written as follows:

$$
U_{i}\left(a_{i}\right)=100 \frac{\left(C_{\max }-C_{o u t}\right)}{\left(C_{\max }-C_{\min }\right)} \%
$$

The utility equation for the benefit criteria can be written as follows:

$$
\mathrm{U}_{i}\left(a_{i}\right)=100 \frac{\left(C_{\text {out }}-C_{\min }\right)}{\left(C_{\max }-C_{\min }\right)} \%
$$

$\mathrm{U}_{i}\left(a_{i}\right) \quad$ : the utility value of the "i" criterion for the "i" alternative

$\mathrm{C}_{\max } \quad$ : maximum criteria value
$\mathrm{C}_{\min }$
: minimum criteria value
Cout : the value of the "i" criterion

c. Determine the final grade value by multiplying the value obtained from the normalized standard data criteria value with the normalized criterion weight value. With the following equation:

$$
\begin{aligned}
& U\left(a_{i}\right)=\sum_{J=1}^{m} w_{j} u_{i}\left(a_{i}\right), i=1,2, \ldots m \\
& \mathrm{U}\left(a_{\mathrm{i}}\right) \text { : total value for alternative "i" } \\
& \mathrm{W}_{\mathrm{j}} \text { : the normalized "j" criterion weight value } \\
& \mathrm{U}_{\mathrm{j}}\left(\mathrm{a}_{\mathrm{i}}\right) \text { : the utility value of the " } \mathrm{j} \text { " criteria for the "ij" }
\end{aligned}
$$

\section{RESULT AND DISCUSSION}

The criteria, that will be used in this research are: price, quality, delivery and service. These criteria is obtained from the results of interviews with informants. From the three kinds of questionnaires filled in by subject matters experts, rankings are generated based on the following method:

\subsection{Fuzzy AHP}

From the results of filling out the questionnaire for each respondent, from total 12 respondents, the average final values are obtained, and the Fuzzy AHP final rank of supplier assembly parts can be found in table 4 :

Table 4. Fuzzy AHP Final ranking results

\begin{tabular}{lcccccccccccccc}
\hline Alternative & $\mathbf{1}$ & $\mathbf{2}$ & $\mathbf{3}$ & $\mathbf{4}$ & $\mathbf{5}$ & $\mathbf{6}$ & $\mathbf{7}$ & $\mathbf{8}$ & $\mathbf{9}$ & $\mathbf{1 0}$ & $\mathbf{1 1}$ & $\mathbf{1 2}$ & Ave & Rank \\
\hline Supplier 1 & 0,068 & 0,125 & 0,115 & 0,210 & 0,095 & 0,088 & 0,089 & 0,081 & 0,399 & 0,053 & 0,226 & 0,213 & 0,147 & 4 \\
Supplier 2 & 0,042 & 0,115 & 0,062 & 0,051 & 0,033 & 0,042 & 0,030 & 0,057 & 0,011 & 0,011 & 0,044 & 0,039 & 0,045 & 8 \\
Supplier 3 & 0,363 & 0,192 & 0,244 & 0,073 & 0,467 & 0,349 & 0,094 & 0,265 & 0,291 & 0,154 & 0,148 & 0,087 & 0,227 & 1 \\
Supplier 4 & 0,034 & 0,098 & 0,075 & 0,126 & 0,043 & 0,046 & 0,060 & 0,067 & 0,017 & 0,031 & 0,103 & 0,106 & 0,067 & 6 \\
Supplier 5 & 0,090 & 0,118 & 0,129 & 0,090 & 0,122 & 0,092 & 0,304 & 0,121 & 0,142 & 0,426 & 0,181 & 0,146 & 0,163 & 2 \\
Supplier 6 & 0,168 & 0,167 & 0,159 & 0,297 & 0,030 & 0,198 & 0,173 & 0,242 & 0,041 & 0,045 & 0,180 & 0,250 & 0,163 & 3 \\
Supplier 7 & 0,019 & 0,095 & 0,089 & 0,072 & 0,030 & 0,073 & 0,067 & 0,074 & 0,033 & 0,054 & 0,046 & 0,064 & 0,060 & 7 \\
Supplier 8 & 0,215 & 0,091 & 0,128 & 0,080 & 0,180 & 0,111 & 0,184 & 0,093 & 0,065 & 0,226 & 0,072 & 0,093 & 0,128 & 5 \\
\hline
\end{tabular}

From the results of Fuzzy AHP analysis, supplier 3 is the best supplier. It can be seen with the highest value of 0.227 or around $22.7 \%$. This means that from the criteria for price, quality, service and delivery, supplier 3 is the most prioritized supplier from the other seven suppliers. The method of decision making using Fuzzy AHP is a refinement of the analysis produced by AHP. The use of the AHP approach does not completely solve the human thinking style because the resulting value is a single value so it tends to be biased. With Fuzzy AHP, the analysis is improved by using the triangular fuzzy number (TFN) which describes fuzzy mathematical set theory.

\subsection{TOPSIS}

Twelve respondents were selected to fill out the questionnaire. Respondents were selected based on the department that is directly related to the supplier. So that respondents are expected to provide accurate information. From the result 12 
respondents. The average final values are obtained, so that the TOPSIS final rank of supplier assembly parts can be found in table 5 :

Table 5. TOPSIS Final ranking results

\begin{tabular}{|c|c|c|c|c|c|c|c|c|c|c|c|c|c|c|}
\hline \multirow{2}{*}{ Alternative } & \multicolumn{12}{|c|}{ SME } & \multirow[t]{2}{*}{ Ave } & \multirow[t]{2}{*}{ Rank } \\
\hline & 1 & 2 & 3 & 4 & 5 & 6 & 7 & 8 & 9 & 10 & 11 & 12 & & \\
\hline Supplier1 & 0,514 & 0,584 & 0,536 & 0,457 & 0,341 & 0,540 & 0,438 & 0,469 & 0,559 & 0,664 & 0,602 & 0,426 & 0,511 & 3 \\
\hline Supplier2 & 0,178 & 0,376 & 0,230 & 0,180 & 0,080 & 0,251 & 0,224 & 0,300 & 0,254 & 0,275 & 0,231 & - & 0,215 & 8 \\
\hline Supplier3 & 0,681 & 0,789 & 0,740 & 0,452 & 0,850 & 0,749 & 0,460 & 1,000 & 0,565 & 0,560 & 0,504 & 0,484 & 0,653 & 1 \\
\hline Supplier4 & 0,184 & 0,584 & 0,500 & 0,622 & 0,341 & 0,470 & 0,341 & 0,469 & 0,458 & 0,411 & 0,439 & 0,420 & 0,437 & 6 \\
\hline Supplier5 & 0,428 & 0,329 & 0,384 & 0,545 & 0,341 & 0,388 & 0,566 & 0,343 & 0,499 & 0,549 & 0,562 & 0,717 & 0,471 & 5 \\
\hline Supplier6 & 0,578 & 0,688 & 0,616 & 0,560 & 0,211 & 0,621 & 0,408 & 0,409 & 0,544 & 0,515 & 0,538 & 0,343 & 0,503 & 4 \\
\hline Supplier7 & 0,407 & 0,584 & 0,500 & 0,385 & 0,232 & 0,505 & 0,341 & 0,469 & 0,393 & 0,411 & 0,612 & 0,217 & 0,421 & 7 \\
\hline Supplier8 & 0,602 & 0,580 & 0,457 & 0,460 & 0,566 & 0,492 & 0,465 & 0,531 & 0,624 & 0,494 & 0,534 & 0,567 & 0,531 & 2 \\
\hline
\end{tabular}

From the results of the TOPSIS, supplier 3 is the best supplier. With the highest value of 0.663 . This means that from the criteria for price, quality, service and delivery, supplier 3 is the most recommended supplier from the seven other suppliers.

\subsection{SMART}

Rank in the SMART method is obtained from the calculation of the final value obtained from the multiplication of normalized weight with utility. The SMART final rank of supplier assembly parts can be found in table 6 :

Table 6. SMART Final ranking results

\begin{tabular}{llllllllllllllll}
\hline \multirow{2}{*}{ Aternative } & $\mathbf{1}$ & $\mathbf{2}$ & $\mathbf{3}$ & $\mathbf{4}$ & $\mathbf{5}$ & $\mathbf{6}$ & $\mathbf{7}$ & $\mathbf{8}$ & $\mathbf{9}$ & $\mathbf{1 0}$ & $\mathbf{1 1}$ & $\mathbf{1 2}$ & Ave & Rank \\
\hline Supplier 1 & 0,551 & 0,619 & 0,571 & 0,500 & 0,256 & 0,429 & 0,405 & 0,464 & 0,631 & 0,679 & 0,583 & 0,286 & 0,498 & 3 \\
Supplier 2 & 0,077 & 0,190 & 0,143 & 0,095 & 0,026 & 0,143 & 0,143 & 0,286 & 0,179 & 0,179 & 0,179 & 0,000 & 0,137 & 8 \\
Supplier 3 & 0,846 & 0,905 & 0,786 & 0,500 & 0,949 & 0,857 & 0,429 & 1,000 & 0,583 & 0,536 & 0,565 & 0,369 & 0,694 & 1 \\
Supplier 4 & 0,103 & 0,619 & 0,500 & 0,607 & 0,256 & 0,286 & 0,286 & 0,464 & 0,464 & 0,357 & 0,429 & 0,500 & 0,406 & 6 \\
Supplier 5 & 0,474 & 0,429 & 0,357 & 0,607 & 0,256 & 0,214 & 0,595 & 0,179 & 0,452 & 0,643 & 0,542 & 0,667 & 0,451 & 5 \\
Supplier 6 & 0,551 & 0,714 & 0,643 & 0,548 & 0,077 & 0,500 & 0,357 & 0,393 & 0,571 & 0,464 & 0,560 & 0,405 & 0,482 & 4 \\
Supplier 7 & 0,333 & 0,619 & 0,500 & 0,393 & 0,103 & 0,357 & 0,286 & 0,464 & 0,393 & 0,357 & 0,577 & 0,119 & 0,375 & 7 \\
Supplier 8 & 0,654 & 0,702 & 0,464 & 0,488 & 0,462 & 0,286 & 0,440 & 0,536 & 0,631 & 0,357 & 0,524 & 0,524 & 0,506 & 2 \\
\hline
\end{tabular}

From the results of the SMART analysis, supplier 3 is the best supplier. It can be seen that the highest value is 0.694 . This means that from the criteria for price, quality, service and delivery, supplier 3 is the most prioritized supplier of the other suppliers.

\subsection{Comparison Between Methods}

From the three methods used, namely Fuzzy AHP, TOPSIS and SMART, the ranking results of each supplier are obtained see table 7 . The following is rank comparison result from the three methods.

Table 7. The results of the final ranking between methods

\begin{tabular}{lccc}
\hline Alternative & \multicolumn{3}{c}{ Rank } \\
& FAHP & TOPSIS & SMART \\
\hline Supplier 1 & 4 & 3 & 3 \\
Supplier 2 & 8 & 8 & 8 \\
Supplier 3 & 1 & 1 & 1 \\
Supplier 4 & 6 & 6 & 6 \\
Supplier 5 & 2 & 5 & 5 \\
Supplier 6 & 3 & 4 & 4 \\
Supplier 7 & 7 & 7 & 7 \\
Supplier 8 & 5 & 2 & 2 \\
\hline
\end{tabular}

TOPSIS and SMART methods can be seen to have the same rank order from rank-1 to 8 . The SMART method tends to be simpler and more practical in its use, because the SMART method has fewer stages to the TOPSIS method. The SMART method uses a linear adaptive model to 
predict the value of each alternative. SMART is more widely used because of its simplicity in responding to the needs of decision makers and the way it analyse responses. The analysis is best transparent so that this method provides a high level of understanding of the problem and is acceptable to the decision maker. The weighting on SMART uses a scale of 0 to 1 , making it easier to calculate and compare the values for each alternative [19].

The Fuzzy AHP method has a final ranking value that is slightly different from the TOPSIS and SMART methods. The same supplier rank for all three methods are rank number 6, 7 and 8 . The Fuzzy AHP method can eliminate subjectivity, because the assessment is converted into a triangular fuzzy number (TFN). Fuzzy AHP tends to have longer stages when compared to the SMART and TOPSIS methods. The application of fuzzy numbers differentiates between the Fuzzy AHP method and other methods.

Fuzzy AHP, TOPSIS and SMART methods can be used in making decisions with their respective advantages and disadvantages. From the three methods used in the study, the supplier with the highest value was selected which is supplier \#3. And the lowest3 result for supplier \#4, supplier \#7 and supplier \#2.

By using the criteria of price, quality, delivery and service obtained from the results of interviews and questionnaires filled out by subject matter experts and processed using the Fuzzy AHP, TOPSIS and SMART methods, the supplier ranking is obtained.

Based on management policy, the three suppliers with the lowest scores will be replaced by other suppliers or will be re-evaluated. This study is used by the company as a tool to make scientific and objective decisions. This study helps managers in making decisions to solve semistructured problems, increases the effectiveness of decision-making by managers and supports manager's assessment rather than replacing it [20].

By using this method, it can eliminate the subjectivity of the assessment. Seeing these results, the three suppliers with the lowest scores are recommended to be replaced or re-evaluated. With the application of this method, it is hoped that PT. XYZ has suppliers who can be used as business partners, long-term relationships and in accordance with company criteria.
The TOPSIS method can provide an optimal alternative, because the calculations depend on positive and negative ideal solutions. The positive ideal solution is defined as the sum of all the best scores that can be achieved for each attribute, while the negative ideal solution consists of all the worst scores achieved for each attribute. TOPSIS considers both the distance to the positive ideal solution and the distance to the negative ideal solution by taking the relative proximity to the positive ideal solution.

\section{CONCLUSION}

Based on the previous studies, criteria for quality, price, service and delivery are important criteria in selecting suppliers. Using Fuzzy AHP, TOPSIS and SMART methods, the same highest ranking supplier is resulted, which is supplier\#3, as well as the same three lowest rank of suppliers which are supplier\#2, \#7 and \#2. For the three suppliers with the lowest values, it is recommended for the company to re-evaluate the suppliers.

The Fuzzy AHP method tends to have longer stages in determining rankings when compared to the SMART and TOPSIS methods. However, the Fuzzy AHP method can eliminate the subjectivity and of the assessment because the assessment is converted into a triangular fuzzy number (TFN). The TOPSIS method is longer than the SMART method, even though the final results in the case are the same. The TOPSIS method emphasizes getting the optimal alternative with the stages. Because in its calculations, TOPSIS considers the distance to the positive ideal solution and the distance to the negative ideal solution by taking the relative proximity to the positive ideal solution. The SMART method tends to be simpler and more practical in its use, because of its simple steps, so this method is widely used. The analysis is best transparent so that this method provides a high level of understanding of the problem and is acceptable to the decision maker.

Companies can also apply the Fuzzy AHP, TOPSIS and SMART methods not only for supplier selection but also for assisting in other decision-making, for example selecting locations for warehouse placement, salesmen, branch offices and others.

For further research, it is recommended to try other case to compare the results from the three methods: Fuzzy AHP, TOPSIS and SMART to check to consistent findings, as well as to add other criteria and sub-criteria that affect supplier 
performance and use different methods for example ANP, SAW and others.

\section{REFERENCES}

[1] A. Kusaeri, M. Hermansyah, and $H$. Bashori, "Analisis Pemilihan Supplier menggunakan Pendekatan Metode Analitychal Hierarchy Process di Pt. XX," $J$. Knowl. Ind. Eng., vol. 3, no. 2, pp. 51-61, 2016, [Online]. Available: http://download.garuda.ristekdikti.go.id/arti cle. php?article $=827045 \&$ val $=13427 \&$ title $=$ ANALISIS PEMILIHAN SUPPLIER MENGGUNAKAN PENDEKATAN METODE ANALYTICAL HIERARCHY PROCESS DI PT XX

[2] J. E. Turban, Efraim \& Aronson, Decision Support Systems and Intelligent Systems. 6th edition, vol. 4. Pearson Prentice-Hall Upper Saddle River, NJ, USA:, 2001.

[3] M. J. Suarez Bello, "A case study approach to the supplier selection process," ProQuest Dissertations and Theses. University of Puerto Rico, Mayaguez (Puerto Rico), pp. 142-142 p., 2004 , [Online].

Available:http://search.proquest.com.librar y.capella.edu/docview/305074709?accou ntid=27965\%5Cnhttp://wv9la5ld3p.search. serialssolutions.com.library.capella.edu/?c tx_ver=Z39.882004\&ctx_enc=info:ofi/enc: UTFF\&rfr id=info:sid/ProQuest+Dissertati ons+\%26+Theses+Global\& .

[4] H. H. Azwir, "Pemilihan Supplier Menggunakan Metode Analytic Network Process Di Pt United Tractors Pandu Engineering," J. Tek. Ind., vol. 18, no. 2, p. 103,2017. Available at doi: 10.22219/jtiumm.vol18.no2.103-112.

[5] H. K. Chan and X. Wang, "Fuzzy Hierarchical Model for Risk Assessment," Fuzzy Hierarchical Model Risk Assess., pp. 25-43, 2013. Available at doi: 10.1007/978-1-4471-5043-5_3.

[6] Z. Güngör, G. Serhadlıoğlu, and S. E. Kesen, "A fuzzy AHP approach to personnel selection problem," Appl. Soft Comput., vol. 9, no. 2, pp. 641-646, 2009, Available at doi: 10.1016/j.asoc.2008.09.003.

[7] P. Wang, Z. Zhu, and Y. Wang, "A novel hybrid MCDM model combining the SAW, TOPSIS and GRA methods based on experimental design," Inf. Sci. (Ny)., vol. 345 , pp. $27-45,2016$. Available at doi: 10.1016/j.ins.2016.01.076

[8] C. Leake, P. Goodwin, and G. Wright, "Decision Analysis for Management Judgment (2nd Edn).," J. Oper. Res. Soc., vol. 49 , no. 10, p. 1107,1998 . Available at doi: $10.2307 / 3010535$

[9] R. Rodriguez and B. Lev, "Models, Methods, Concepts and Applications of the Analytic Hierarchy Process (Book).," Interfaces (Providence)., vol. 32, no. 6, p. 93, 2002, [Online]. Available: http://search.ebscohost.com/login.aspx?di rect $=$ true \& db=bth\&AN=8969563\&lang $=z h$ -cn\&site=ehost-live.

[10] P. S. W. Fong and S. K. Y. Choi, "Final contractor selection using the analytical hierarchy process," Constr. Manag. Econ., vol. 18 , no. 5, pp. 547-557, 2000. Available at doi: $10.1080 / 014461900407356$.

[11] A. A. Shojaie, S. Babaie, E. Sayah, and D. Mohammaditabar, "Analysis and Prioritization of Green Health Suppliers Using Fuzzy ELECTRE Method with a Case Study," Glob. J. Flex. Syst. Manag., vol. 19, no. 1, pp. 39-52, 2018. Available at doi 10.1007/s40171-017-0168-2.

[12] A. Faisol, M. Muslim, and H. Suyono, "Komparasi Fuzzy AHP Dengan AHP Pada Sistem Pendukung Keputusan Investasi Properti," J. EECCIS, vol. 8, no. 2, pp. 123-128, 2014, [Online]. Available: https://jurnaleeccis.ub.ac.id/index.php/eec cis/article/view/249/219.

[13] D. Y. Chang, "Applications of the extent analysis method on fuzzy AHP," Eur. J. Oper. Res., vol. 95, no. 3, pp. 649-655, 1996. Available at doi: 10.1016/03772217(95)00300-2

[14] P. Astuti, "Pemilihan Supplier Bahan Baku Dengan Menggunakan Metoda Analytical Hierarchy Process ( Ahp )," Indones. J. Comput. Infrmation Technol. Nusa Mandiri, vol. 1, no. 2, pp. 30-36, 2016.

[15] S. Kusumadewi, S. Hartati, A. Harjoko, and R. Wardoyo, "Fuzzy multi-attribute decision making (fuzzy madm)," 
Yogyakarta Graha IImu, pp. 78-79, 2006, [Online]. Available: Google Document.

[16] R. Meliana, "Penerapan Metode TOPSIS pada Aplikasi Keputusan Seleksi Peyaluran Tenaga Kerja dalam Bursa Alumni," Universitas Pendidikan Indonesia, 2011.

[17] J. Achebo, "Application of Multi-Criteria Decision Making Optimization Tool for Determining Mild Steel Weld Properties and Process Parameters Using the TOPSIS," Int. J. Mater. Sci. Appl., vol. 4, no. 3 , p. 149,2015, Available at doi: 10.11648/j.jmsa.20150403.12.

[18] C. Leake, P. Goodwin, and G. Wright, Decision Analysis for Management Judgment (2nd Edn)., vol. 49, no. 10. John Wiley \& Sons, 1998.

[19] T. L. Saaty, "How to make a decision," Int Ser. Oper. Res. Manag. Sci., vol. 175, pp. 1-21, 2012. Available at doi: 10.1007/9781-4614-3597-6_1.

[20] E. Sonalitha, M. Sarosa, and A. Naba, "Pemilihan Pemasok Bahan Mentah pada Restoran Menggunakan Metode Fuzzy Analytical Hierarchy Process," J. EECCIS, vol. 9, no. 1, pp. 49-54, 2015.

\section{Author Biography}

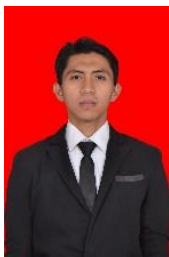

\section{Samdan Wibawa}

Industrial Engineering Department, BINUS Graduate Program - Master of Industrial Engineering, Bina Nusantara University, Jakarta, Indonesia

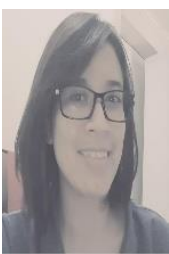

\section{Ardhianiswari Diah Ekawati}

Industrial Engineering Department, BINUS Graduate Program - Master of Industrial Engineering, Bina Nusantara University, Jakarta, Indonesia

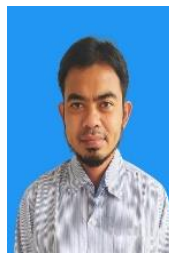

\section{Budian Maryadi}

Industrial Engineering Department, BINUS Graduate Program - Master of Industrial Engineering, Bina Nusantara University, Jakarta, Indonesia

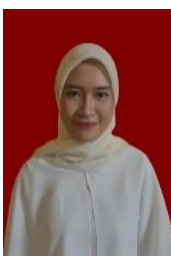

\section{Nurafni Fitriyani}

Industrial Engineering Department, BINUS Graduate Program - Master of Industrial Engineering, Bina Nusantara University, Jakarta, Indonesia

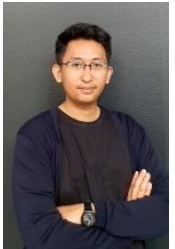

Anak Agung Ngurah Perwira Redi Industrial Engineering Department, BINUS Graduate Program - Master of Industrial Engineering, Bina Nusantara University, Jakarta, 